DOI: http://dx.doi.org/10.18524/2307-4663.2021.1(51).228977

UDC 579.64:635-18

Y.A. Shvets, K.D. Krylova, N.V. Limanska

Odesa I.I. Mechnykov National University,

2, Dvorianska str., Odesa, 65082, Ukraine,

e-mail: julianna.shvets@gmail.com

\title{
EFFECT OF BACILLUS MEGATERIUM ONU 500 ON THE GERMINATION AND GROWTH OF SUNFLOWER SEEDLINGS
}

\begin{abstract}
The aim of the study was to evaluate the effect of Bacillus megaterium ONU 500 on the germination and growth of sunflower seedlings. Materials and methods. Sunflower seeds were sown in containers with soil inoculated with a suspension of bacteria B. megaterium ONU 500 in concentration of $10^{6} \mathrm{CFU} / \mathrm{ml}$. After 21 days growth characteristics of seedlings were compared: germination, average height, root length, leaf area, dry weight. Effect of these microorganisms on biofilm formation on roots was investigated with light microscopy. Results. Inoculation of soil with B. megaterium ONU 500 resulted in the positive effect on roots length (increase by 21\%), leaf area (increase by 22\%) and dry weight of seedlings (increase by $17.8 \%$ ). No significant effect on germination and plant height was observed. On the roots of plants grown in soil treated with B. megaterium ONU 500 more developed biofilms with well formed matrix were observed, which indicates the stimulation of ability of plant and soil microbiota to form biofilms in presence of bacilli from the studied strain. Conclusion. The investigations demonstrated that bacteria of B. megaterium ONU 500 strain caused a positive effect on development of sunflower seedlings and formation of biofilms on their roots.
\end{abstract}

Key words: B. megaterium, sunflower, growth characteristics of seedlings, biofilm.

Bacillus megaterium de Bary - representatives of plant and soil microbiota. Antagonistic and phytostimulative properties of these microorganisms make them useful for application in agriculture $[11 ; 12]$. Use of $B$. megaterium as a biofertilizer helps to stimulate plant growth, promotes better decomposition of organic phosphorus and increases resistance to various stresses and a wide range of pathogens $[10 ; 13]$.

Nowadays, protection of the environment against contamination with chemical fertilizers and pesticides becomes increasingly important. Use of different chemicals leads to depletion of soil fertility and reduced quality of agricultural products. Biological products based on beneficial soil- and plant-associated bacteria can be used as alternative methods to stimulate plant growth, protect them from pathogens and increase chances of survival under stressful conditions [14; 17].

Microorganisms $B$. megaterium are able to synthesize phytohormones that promote plant growth and increase yield of horticultural crops. They also cause

( Ю.А. Швець, К.Д. Крилова, Н.В. Ліманська, 2021 
visible improvement of morphological characteristics of plants and reduce seed germination time. B. megaterium produce cytokinins, indole-3-acetic and abscisic acids, which play an important role in plant growth regulation, cytokinesis and in the regulation of environmental stress $[16 ; 19]$.

Modern crop production is based on the ideas of using biological preparations containing microbial phytohormones due to the simplicity and cheapness of their production [14]. In addition, an important factor in yielding a high-quality crop is the control of diseases. Some strains of B. megaterium are described as agents of biological control - they can colonize the rhizosphere of plants and provide protection against pathogenic microorganisms $[7 ; 10 ; 13 ; 16]$.

$B$. megaterium are phosphate-mobilizing bacteria that are able to absorb phosphorus from compounds inaccessible to plants and transport them to roots. They also regulate water and minerals metabolism of plants. As a result, increased resistance of plants to drought, heat and salt stress is observed, which makes $B$. megaterium extremely attractive for use in arid regions [19].

Due to phytostimulating properties useful for agriculture, the aim of the work was to evaluate the effect of Bacillus megaterium ONU 500 on the germination and growth of sunflower seedlings.

\section{Materials and methods}

The culture of $B$. megaterium ONU 500 was cultivated overnight at $28^{\circ} \mathrm{C}$ in liquid LB medium (trypton $-10 \mathrm{~g} / \mathrm{l}$, yeast extract $-5 \mathrm{~g} / \mathrm{l}, \mathrm{NaCl}-10 \mathrm{~g} / \mathrm{l}$ ) [9]. The concentration of overnight culture was measured using a SmartSpec spectrophotometer (BioRad). The culture was diluted with tap water to $10^{6} \mathrm{CFU} / \mathrm{ml}$ according to Tverdokhlib et al. [18].

Sunflower seeds [4] were sown in plastic containers with peat soil (4 seeds in each container) to a depth of $0.5-1.0 \mathrm{~cm}$ (fig. 1).

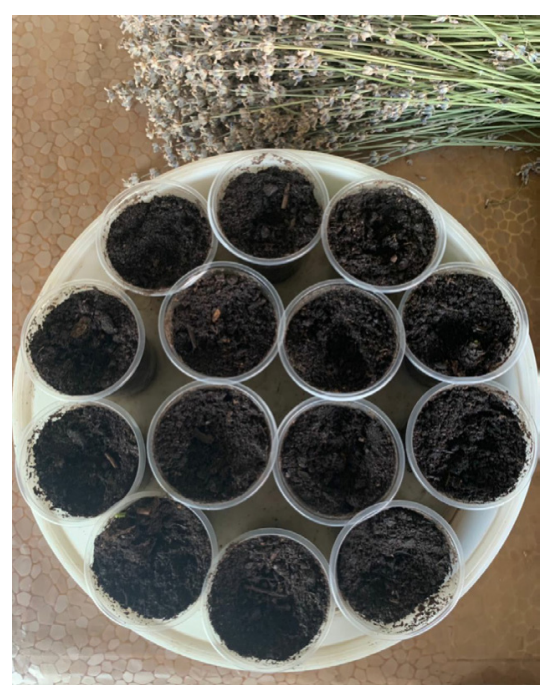

A

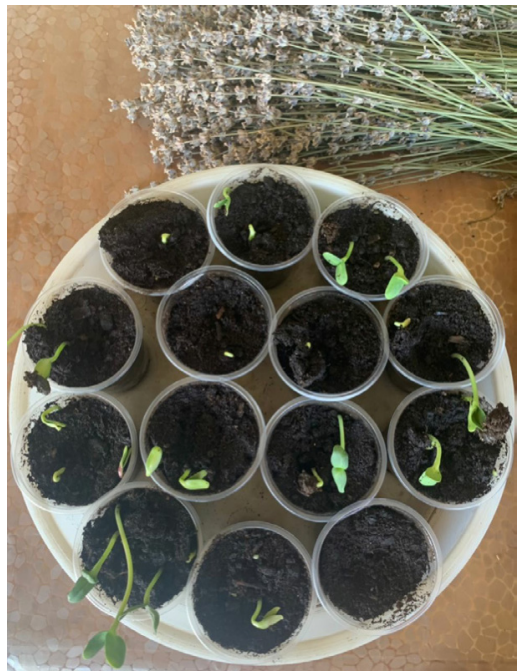

$\mathrm{B}$

Fig. 1. Sunflower seedlings on the first (A) and third (B) day after sowing 
The soil was inoculated with a suspension $(50 \mathrm{ml})$ of $B$. megaterium $\mathrm{ONU}$ 500 in concentration of $10^{6} \mathrm{CFU} / \mathrm{ml}$ on the first day of the experiment. The soil in a control variant was poured with the equivalent volume of water. Three independent experiments of 200 seeds in each variant were conducted.

Sunflower plants growth was observed for three weeks under the next conditions: open air, partial shade, 12-hour daylight, temperature $28 \pm 2{ }^{\circ} \mathrm{C}$, moderate humidification. Biometric indexes were measured on $22^{\text {nd }}$ day of the experiment - on the phase of 5-6 leaves. Seed germination, average seedling height, seedling root length and seedling leaf area were evaluated [8]. Average dry weight of seedlings was measured. Average values and confidence intervals were calculated using the Excel application package.

To study the effect of B. megaterium ONU 500 on biofilm formation, microscopy of biofilms was performed. Roots of sunflower seedlings were dyed with $1 \%$ solution of acridine orange for 10 minutes. The stained roots were dried on a glass slide and examined under a light microscope with a total magnification of 100x. The level of biofilm formation was assessed on a scale according to Galkin et al. [1]:

Table

The evaluation criteria of the formation of biofilms

\begin{tabular}{|l|l|}
\hline \multicolumn{1}{|c|}{ Criteria } & \multicolumn{1}{c|}{ Description } \\
\hline- & Biofilms are not formed \\
\hline+ & Individual attached cells without formation of biofilms \\
\hline++ & Individual developed microcolonies \\
\hline+++ & Developed biofilms with gaps in the structure \\
\hline++++ & Developed biofilms with matrix and without gaps \\
\hline
\end{tabular}

Biofilm studies were performed in each independent experiment.

\section{Results and discussion}

Germination of plants grown in the soil inoculated with B. megaterium ONU $500(87.3 \pm 2.9 \%)$ did not significantly differ from the control $(85.0 \pm 2.5 \%)$.

Similarly, inoculation of soil with bacilli of this strain did not significantly affect the height of sunflower seedlings (fig. 2, a).

At the same time, a significant positive effect of inoculation with $B$. megaterium ONU 500 on the root length was observed. The average root length increased by $21.08 \%$ (fig. 2, b).

The results of Dahmani et al. confirmed that strains of B. megaterium had positive effect on the growth and development of plant roots [10]. These micro- 
organisms also contribute to the formation of lateral roots and increase the length of root hair, which is necessary for collection and transfer of water and minerals present in soil to roots $[10 ; 13 ; 15]$.

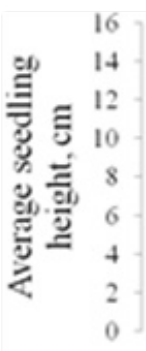

a

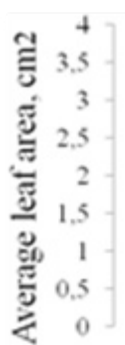

$\mathrm{c}$

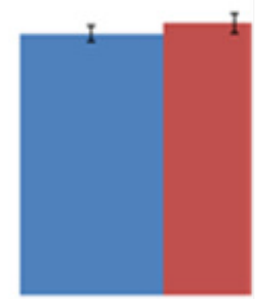

a control $=\mathrm{ONU} 500$

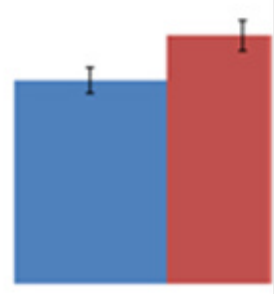

$=$ control $=\mathrm{ONU} 500$

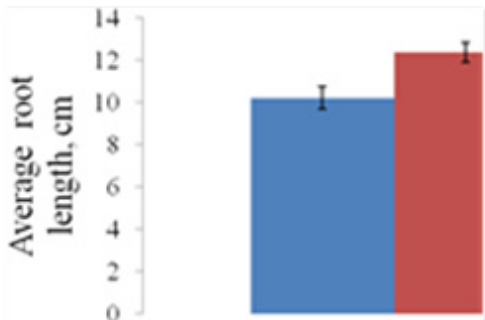

b

$=$ control $=\mathrm{ONU} 500$

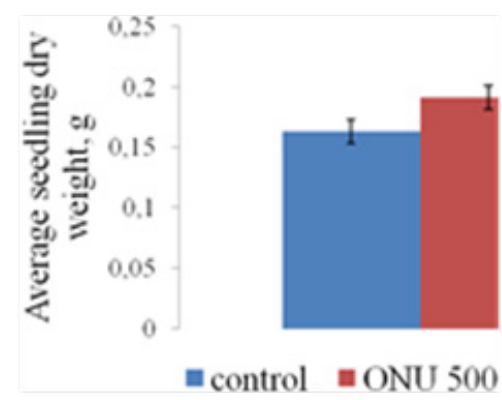

Fig. 2. Biometric indexes of the sunflower seedlings:

$\mathrm{a}$ - average height $(\mathrm{cm}) ; \mathrm{b}$ - average length of roots $(\mathrm{cm}) ; \mathrm{c}$ - average leaf area $\left(\mathrm{cm}^{2}\right)$; $\mathrm{d}$ - average dry weight (g).

Treatment with a suspension of bacilli increased leaf area by $21,93 \%$ (fig. 2 , c). Phytostimulation effect of inoculation with bacilli was also observed in case of dry weight of seedlings: it increased by $17.8 \%$ as compared with the control (fig. $2, \mathrm{~d})$.

The results of our study coincide with the literature data. Previous studies of Tverdokhlib et al. [18], Teslyuk et al. [10] and Dahmani et al. [5] indicate the significant phytostimulatory effect of B. megaterium strains on plant growth, development of roots and vital functions $[5 ; 10 ; 18]$. Literature data indicated that cultural medium LB by itself did not cause the stimulation effect [16] but in majority of cases inhibited plant growth [6]. The results of our previous studies also have shown the inhibitory effect of LB and LB mixed with MRS medium on germination and plants growth $[2 ; 3]$. According to this, we could suggest that increasing of some biometric indexes of sunflower seedlings could be explained by the influence of bacteria $B$. megaterium ONU 500 but not the cultural medium.

It could be hypothesized that improvement of biometric indexes of the plants occurred due to ability of $B$. megaterium to synthesize phytohormones $[7 ; 10 ; 15$; $16 ; 19]$, but this suggestion needs further investigations.

The influence of $B$. megaterium ONU 500 on formation of biofilms on roots of sunflower seedlings was studied. In the control variant, slightly developed bio- 
films on roots were formed. In presence of bacteria B. megaterium ONU 500 more developed, mature biofilms with well-formed matrix $(++++)$ were observed in all experimental variants. The level of biofilm formation became higher in plants grown in the soil treated with bacilli of this strain (fig. 3).

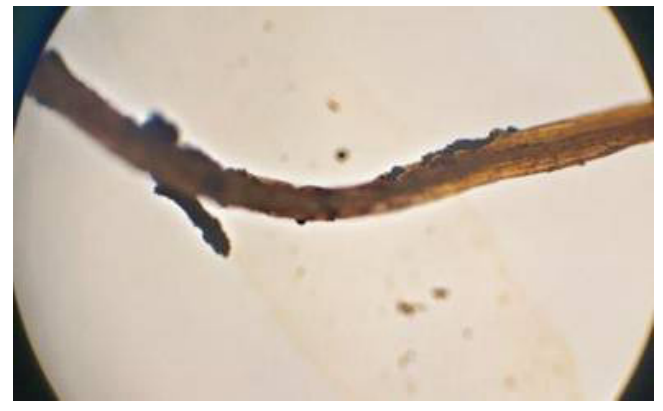

Control

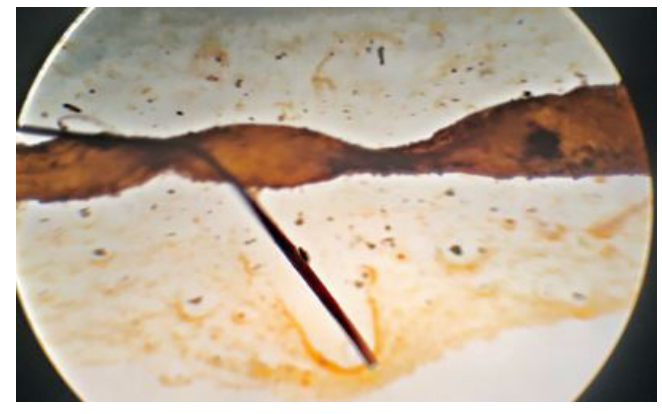

B. megaterium ONU $500(++++)$

Fig. 3. Biofilms on the sunflower seedlings roots in the control (without inoculation) and experimental (after inoculation of soil with $B$. megaterium ONU 500) variants (100x)

Microorganisms, in particular bacilli, are able to form biofilms on plant roots and integrate into natural biofilms of other microorganisms, enhancing their protective properties [20].

The obtained results allow us to suggest that bacteria $B$. megaterium ONU 500 are able to enhance the formation of biofilms by other representatives of plant and soil microbiota. As a result, developed integrated biofilms on the roots of sunflower plants grown in the soil inoculated with B. megaterium ONU 500 were formed as compared with the plants from the non inoculated soil.

Thus, the study of B. megaterium ONU 500 has shown that these bacteria could be used for stimulation of plant growth. The further investigation of the mechanisms of biofilm formation in presence of B. megaterium ONU 500 could elucidate another positive aspect of using bacilli - as stimulators of plant and soil microbiota.

\section{Conclusions}

The investigations demonstrated that bacteria of B. megaterium ONU 500 strain caused a positive effect on development of sunflower seedlings and formation of biofilms on their roots. 


\title{
Ю.А. Швець, К.Д. Крилова, Н.В. Ліманська
}

Одеський національний університет імені I.I. Мечникова, вул. Дворянська, 2, Одеса 65082, Україна, e-mail: julianna.shvets@gmail.com

\section{ВПЛИВ ВACILLUS MEGATERIUM ОНУ 500 НА ПРОРОСТАННЯ ТА РІСТ СІЯНЦІВ СОНЯШНИКА}

\begin{abstract}
Реферат
Мета. Дослідити вилив В. mеgaterium ОНУ 500 на проростання насіння та ріст сіянців сонямника. Матеріали і методи. Насіння соняшника висівали у контейнери із грунтом, в який вносили суспензію бактерій штаму В. megaterium ОНУ 500 у кониентрації $10^{6} \mathrm{KУO/мл.} \mathrm{Через} 21$ день після висіву визначали ростові характеристики паростків: схожість, середню висоту паростків, довжину кореня, площу листової пластинки, суху масу паростків. Методом світлової мікроскопії оцінено вилив даних мікроорганізмів на формування біоплівки на коренях. Результати. За інтродукиії бактерій B. mеgaterium ОНУ 500 у грунт спостерігали збільшення довжини коренів сіянців сонямника на $21 \%$, площі листків - на $22 \%$, сухої маси паростків-на $17,8 \%$. На схожість та висоту рослин суттевого впливу не виявлено. На коренях рослин, які росли у грунті з інтродукованими В. mеgaterium ОНУ 500, спостерігали більш розвинені біоплівки з повністю сформованим матриксом, що свідчить про підсилення здатності мікробіоти рослин і грунту утворювати біоплівки під впливом бачил даного штаму. Висновок. Проведені дослідження показали, що бактерії штаму В. mеgateriuт ОНУ 500 чинять позитивний вилив на розвиток сіянців соняиника та формування біоплівок на їх корінні.
\end{abstract}

Ключові слова: B. megaterium, соняшник, біометричні показники паростків, біоплівка.

Ю.А. Швец, Е.Д. Крылова, Н.В. Лиманская

Одесский национальный университет имени И.И. Мечникова, ул. Дворянская, 2, Одесса 65082, Украина, e-mail: julianna.shvets@gmail.com

\section{ВЛИЯНИЕ ВACILLUS MEGATERIUM ОНУ 500 НА ПРОРОСТАНИЕ И РОСТ СЕЯНЦЕВ ПОДСОЛНЕЧНИКА}

\section{Реферат}

Цель. Оченить влияние В. теgaterium ОНУ 500 на прорастание семян и рост сеянцев подсолнечника. Материалы и методы. Семена подсолнечника высевали в контейнеры с почвой, в которую вносили суспензию бактерий итамма В. megaterium ОНУ 500 в концентрации $10^{6} \mathrm{KOE} /$ мл. Через 21 день после посева сравнивали ростовые характеристики ростков: всхожесть, среднюю высоту ростков, длину корня, площадь листовой пластинки, сухую массу проростков. Методом световой микроскопии проведена оценка вли- 
яния этих микроорганизмов на формирование биопленки на корнях. Результаты. Внесение в почву В. теgаteriuт ОНУ 500 привело к увеличению длины корней сеянцев на 21\%, площуади листьев - на 22\%, сухой массы ростков - на 17,8\%. На всхожесть и высоту растений существенного влияния выявлено не было. На корнях растений, которые росли в почве с интродуцированными В. теgаtеrium ОНУ 500, наблюдались более развитые биопленки с полностью сформированным матриксом, что свидетельствует о повышении способности микробиоты растений и почвы образовывать биопленки под влиянием бацилл данного штамма. Вывод. Проведенные исследования показали, что бактерии итамма В. теgаtеrium ОНУ 500 оказывают положительное влияние на развитие сеянцев подсолнечника и формирование биопленок на их корнях.

Ключевые слова: B. mеgaterium, подсолнечник, биометрические показатели проростков, биопленка.

\section{СПИСОК ВИКОРИСТАНОЇ ЛІТЕРАТУРИ}

1. Галкін М.Б., Ліманська Н.В., Філіпова Т.О. Формування біоплівки бактеріями Lactobacillus plantarum на коренях рослин Lepidium sativum L. // Мікробіологія і біотехнологія. - 2012. - № 3. - С. 34-43.

2. Коротаєва Н.В., Ліманська Н.В., Страшнова І.В., Іваниия В.О. Вплив бактерій Lactobacillus plantarum ОНУ 87 на розвиток бактеріального раку на рослинах винограду // Мікробіологія і біотехнологія. - 2020. № 2(49). - C. 33-43.

3. Масловська Н.С., Ліманська Н.В. Вплив Lactobacillus plantarum ОНУ 12 і Agrobacterium tumefaciens C58 на проростання і деякі ростові характеристики паростків томату // Вісник Запорізького національного університету. - 2016. - № 2. - С. 129-135.

4. Насіння сільськогосподарських культур. Методи визначення якості: ДСТУ 4138-2002. - [Чинний від 2002-12-28]. - К. : Держспоживстандарт України, 2003. - 172 с. - (Національні стандарти України).

5. Теслюк Н.I., Аврамович I. Удосконалення методів адаптації мікроклонів Paulownia tomentosa до умов in vivo з використанням бактерій Bacillus megaterium ONU 500 // Мікробіологія і біотехнологія. - 2019. - № 3. C. 92-102.

6. Andrade de P.A.M., Pimenta L.S., Silveira Cardillo da B.E., Marcon J., Silva da J.A., Azevedo de J.L., Luz Coelho Novembre da A.D., Quecine M.C. Bacillus sp. RZ2MS9 and the bacteria-free filtrate in the seed germination and growth of maize seedlings // Brazilian Journal of Agriculture. - 2020. Vol. 95(2). - P. 95-105.

7. Akinrinlola R.J., Yuen G.Y., Drijber R.A., Adesemoye A.O. Evaluation of plant growth promotion and predictability of efficacy by in vitro physiological traits // International Journal of Microbiology. - 2018: http://doi. org/10.1155/2018/5686874

8. Bange M.P., Hammer G.L., Milroy S.P., Rickert K.G. Improving estimates of individual leaf area of sunflower // Agronomy Journal. - 2000. - Vol. 9 (4). - P. 761-765. 
9. Bertani $G$. Studies on lysogenesis. I. The mode of phage liberation by lysogenic Escherichia coli // Journal of Bacteriology. - 1951. - Vol. 62. P. 293-300.

10. Dahmani M.A., Desrut A., Moumen B., Verdon J., Mermouri L., Kacem M., Coutos-Thevenot P., Kaid-Harche M., Berges T., Vriet C. Unearthing the plant growth-promoting traits of Bacillus megaterium RmBm31, an endophytic bacterium isolated from root nodules of Retama monosperma // Front. Plant Sci. - 2020. - Vol. 11, № 124: http://doi: 10.3389/fpls.2020.00124

11. Fang $H$., Kang J., Zhang $D$. Microbial production of vitamin $\mathrm{B}_{12}$ : a review and future perspectives // Microb. Cell Fact. - 2017. - Vol. 16. - P. 15.

12. Final Screening Assessment of Bacillus megaterium strain ATCC 14581. En14-314/2018E. - [2018-02-01]. - Canada: Minister of the Environment and Climate Change, 2016. - P. 35.

13. Goswami G., Panda D., Samanta R., Boro R., Modi M., Bujarbaruah M., Barooah K. Bacillus megaterium adapts to acid stress condition through a network of genes: insight from a genome-wide transcriptome analysis // Scientific Reports. - 2018. - Vol. 8. - Article number: 16105: https://doi. org/10.1038/s41598-018-34221-0

14. O'Brien P. Biological control of plant diseases // Australas. Plant Pathol. 2017. - Vol. 46. - P. 293-304.

15. Ortiz-Castro R., Valencia-Cantero E., López-Bucio J. Plant growth promotion by Bacillus megaterium involves cytokinin signaling // Plant Signal Behav. - 2008 -Vol. 3, № 4. - P. 263-265.

16. Porcel R., Zamarreno A., Garcia-Mina J., Aroca R. Involvement of plant endogenous ABA in Bacillus megaterium PGPR activity in tomato plants // BMC Plant. Biol. - 2014. - Vol. 14. - P. 36-43.

17. Tozlu E., Tekiner N., Kotany R., Ortucu S. Investigation on the biological control of Alternaria alternata // Indian J. Agric. Sci. - 2018. - Vol. 88. P. 1241-1248.

18. Tverdokhlib V.S., Limanska N.V., Krylova K.D., Ivanytsia V.O. Ability of Lactobacillus plantarum ONU 12 and Bacillus megaterium ONU 484 to stimulate growth of wheat seedlings and to form biofilms // Мікробіологія i біотехнологія. - 2018. - Vol. 4. - P. 6-18.

19. Wang B., Zhang D., Chu S., Zhi Y., Liu X., Zhou P. Genomic analysis of Bacillus megaterium NCT-2 reveals its genetic basis for the bioremediation of secondary salinization soil // J. Genomics. - 2020. - Vol. 2. - P. 1-11.

20. Wu Y., Cai P., Jing X., Niu X., Ji D., Ashry N.M., Gao C., Huang Q. Soil biofilm formation enhances microbial community diversity and metabolic activity // Environment International. - 2019. - Vol. 132, № 105116: https:// doi.org/10.1016/j.envint.2019.105116.

\section{REFERENCES}

1. Galkin MB, Limanska NV, Philipova TO, Ivanytsia VO. Biofilm formation by Lactobacillus plantarum bacteria on Lepidum Sativum L. roots. Microbiology \& Biotechnology. 2012; 3: 34-43 (in Ukrainian).

2. Korotaeva NV, Limanska NV, Strashnova IV, Ivanytsia VO. Effect of Lac- 
tobacillus plantarum ONU 87 on the development of crown gall in grape. Microbiology \& Biotechnology. 2020; 2(49): 33 - 43 (in Ukrainian).

3. Maslovska NS, Limanska NV. Effect of Lactobacillus plantarum OHY 12 and Agrobacterium tumefaciens C58 on germination and some growth characteristics of tomato seedlings. Bulletin of Zaporizhzhia National University. 2016; 2: 129 - 135 (in Ukrainian).

4. Seeds of agricultural plants. Methods of testing the quality. DSTU 41382002. Kyiv: Derzhpozhivstandart Ukraini: 170 (in Ukrainian).

5. Tesliuk NI, Avramovych I. Improving of adaptation methods of Pavlovnia Tomentosa microclones to conditions in vivo with use of bacteria of Bacillus megaterium ONU 500. Microbiology \& Biotechnology. 2019; 3: 92-102 (in Ukrainian).

6. Andrade de PAM, Pimenta LS, Silveira Cardillo da BE, Marcon J, Silva da JA, Azevedo de JL, Luz Coelho Novembre da AD, Quecine MC. Bacillus sp. RZ2MS9 and the bacteria-free filtrate in the seed germination and growth of maize seedlings. Brazilian Journal of Agriculture. 2020; 95(2): 95 - 105.

7. Akinrinlola RJ, Yuen GY, Drijber RA, Adesemoye AO. Evaluation of plant growth promotion and predictability of efficacy by in vitro physiological traits. International Journal of Microbiology. 2018; http://doi. org/10.1155/2018/5686874

8. Bange MP, Hammer GL, Milroy SP, Rickert KG. Improving estimates of individual leaf area of sunflower. Agronomy Journal. 2000; 9 (4): 761-765.

9. Bertani G. Studies on lysogenesis. I. The mode of phage liberation by lysogenic Escherichia coli. Journal of Bacteriology. 1951; 62: 293-300.

10. Dahmani M, Desrut A, Moumen B, Verdon J, Mermouri L, Kacem M, Coutos-Thevenot P, Kaid-Harche M, Berges T, Vriet C. Unearthing the plant growth-promoting traits of Bacillus megaterium RmBm31, an endophytic bacterium isolated from root nodules of Retama monosperma. Front Plant Sci. 2020; 11: 124-131.

11. Fang H, Kang J, Zhang D. Microbial production of vitamin $B_{12}$ : a review and future perspectives. Microb. Cell Fact. 2017; 16: 15.

12. Final Screening Assessment of Bacillus megaterium strain ATCC 14581. En14-314/2018E. Canada: Minister of the Environment and Climate Change. 2016: 35.

13. Goswami G, Panda D, Samanta R, Boro R, Modi M, Bujarbaruah M, Barooah K. Bacillus megaterium adapts to acid stress condition through a network of genes: insight from a genome-wide transcriptome analysis. Scientific Reports. 2018; 8 (16105).

14. O'Brien P. Biological control of plant diseases. Australas. Plant Pathol. 2017; 46: 293-304

15. Ortíz-Castro R, Valencia-Cantero E, López-Bucio J. Plant growth promotion by Bacillus megaterium involves cytokinin signaling. Plant Signal Behav. 2008; 34: 263-265.

16. Porcel R, Zamarreno A, Garcia-Mina J, Aroca R. Involvement of plant endogenous ABA in Bacillus megaterium PGPR activity in tomato plants. BMC Plant. Biol. 2014; 14: 36-43. 
17. Tozlu E, Tekiner N, Kotany R, Ortucu S. Investigation on the biological control of Alternaria alternata. Indian J. Agric. Sci. 2018; 88: 1241-1248.

18. Tverdokhlib VS, Limanska NV, Krylova KD, Ivanytsia VO. Ability of Lactobacillus plantarum ONU 12 and Bacillus megaterium ONU 484 to stimulate growth of wheat seedlings and to form biofilms. Microbiology \& Biotechnology. 2018; 4: 6-18.

19. Wang B, Zhang D, Chu S, Zhi Y, Liu X, Zhou P. Genomic analysis of Bacillus megaterium NCT-2 reveals its genetic basis for the bioremediation of secondary salinization soil. J. Genomics. 2020; 2: 1-11.

20. Wu Y, Cai P, Jing X, Niu X, Ji D, Ashry NM, Gao C, Huang Q. Soil biofilm formation enhances microbial community diversity and metabolic activity. Environment International. 2019; 132(105116): https://doi.org/10.1016/j.envint.2019.105116.

Стаття надійшла до редакції 16.02..2021р. 